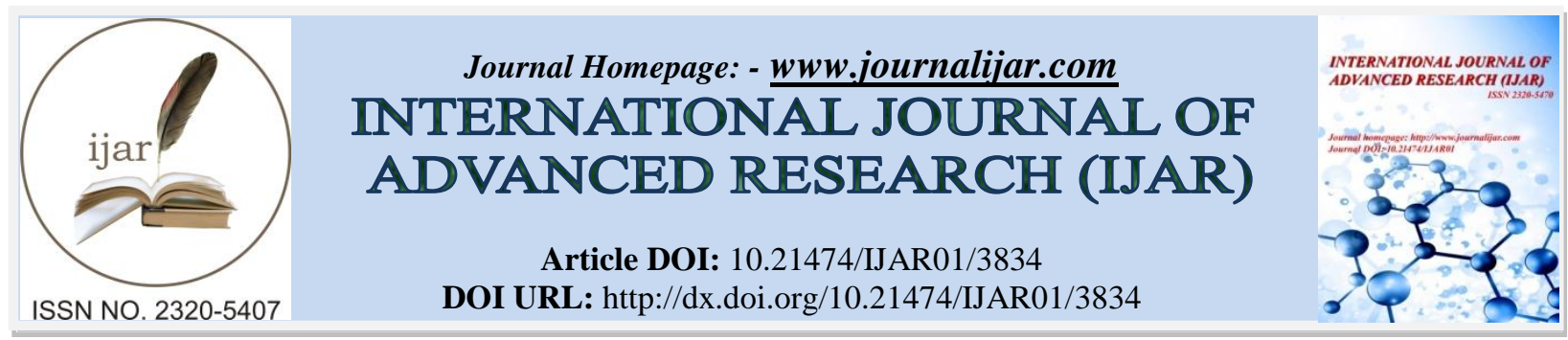

RESEARCH ARTICLE

\title{
OPTIMIZATION OF BACTERIAL INOCULUM CONCENTRATION AND pH FOR THE PRODUCTION OF AMYLASE AND PROTEASE USING Proteus sp. FROM SAGO EFFLUENT.
}

\section{S. Kavipriya ${ }^{1}$ and P. Kousalya ${ }^{2}$.}

1. II-M.Sc. Biochemistry, Department of Biochemistry, Bharathidasan College of Arts and Science, Erode, Tamilnadu, India.

2. Assistant Professor, Department of Biochemistry, Bharathidasan College of Arts and Science, Erode, Tamilnadu, India.

\section{Manuscript Info}

[.........................

Manuscript History

Received: 01 February 2017

Final Accepted: 02 March 2017

Published: April 2017

Key words:-

Amylase, Protease, $\mathrm{pH}$, Bacterial inoculum

\section{Abstract}

Sago is the edible starch in the form of globules extracted from tubers of Manihotesculenta commonly known as Tapioca/Cassava plant. Sago effluent contains large amount of organic material which affect the fertility of soil in agricultural lands. The aim of this study was to isolate and identify amylase and protease producing bacterial strain from sago factory effluent and it is identified as Proteus sp.Optimization of culture conditions such as various concentration of bacterial inoculum $(0.5 \%, 1.0 \%, 1.5 \%$ and $2.0 \%)$ and various range of $\mathrm{pH}(6,7,8,9)$ was performed at different time interval $(24 \mathrm{hrs}, 48 \mathrm{hrs}$ and $72 \mathrm{hrs})$ for the maximum production of amylase and protease using Proteus sp. isolated from sago effluent. Bacterial inoculum concentration of $1.0 \%$ and $2.0 \%$ shows $100 \mu \mathrm{g} / \mathrm{ml}$ of amylase production, $420 \mu \mathrm{g} / \mathrm{ml}$ of protease was produced by $0.5 \%, 1.0 \%$ and $1.5 \%$ bacterial inoculum concentration and the bacterial inoculum concentration of $0.5 \%$ and $1.0 \%$ shows $8000 \mu \mathrm{g} / \mathrm{ml}$ of protein production at 72 hours incubation period. Optimum $\mathrm{pH}$ for the production of amylase and protease was found to be 9 . Amylase and protease production at $\mathrm{pH} 9$ was found to be $126 \mu \mathrm{g} / \mathrm{ml}$ and $690 \mu \mathrm{g} / \mathrm{ml}$. Protein production at $\mathrm{pH} 9$ was found to be $1200 \mu \mathrm{g} / \mathrm{ml}$.

Copy Right, IJAR, 2017,. All rights reserved.

\section{Introduction:-}

The sago industry is a water-intensive industry, as the processing of sago requires several washing cycles and generates 30,000-35,000 liters of effluent per tonne of sago produce. This effluent is acidic and highly organic in nature with chemical oxygen demand (COD) of 5,000-7,000 mg per liter. Those major pollutants specific for this sago effluent are higher amounts of dissolved organic solids, suspended organic solids, BOD and COD. Thus, these effluents pose a serious threat to the environment and quality of life in the rural area, especially. In the rural areas, it contributes to infertility of the farm land, in case of leaving the untreated effluent in agricultural fields, and to water pollution, when discharged into water bodies. Thus, pollution-control is becoming a major problem for the sago industry. Also, there is no standardized cost effective design developed for the sago manufactures; neither by any institution and nor by the pollution control board itself. Problem posed by pollution and high cost of effluent

Corresponding Author:- P. Kousalya.

Address:- Assistant Professor, Department of Biochemistry, Bharathidasan College of Arts and Science, 
treatment plants needs to be rectified for the betterment of both economy and environment (Anbukumar et al., 2014).

Enzymes are substances present in the cells of living organisms in minute amounts and are capable of speeding up chemical reactions (associated with life processes), without themselves being altered after the reaction. They accelerate the velocity of the reaction without necessarily initiating it (Oyeleke and Oduwole, 2009).

Extracellular proteases are naturally produced by microorganisms mainly to degrade large polypeptides in the medium into peptides and amino acids before cellular uptake. Man has commercially exploited such enzymes to assist in protein breakdown in various industrial processes (Synowiecki, 2010). About 75\% of world sales of industrial enzymes applications are hydrolytic enzymes constitutes about $60 \%$ (Rai et al., 2010). Microorganisms offer an attractive source of protease enzymes because they can be cultured in large quantities in a short period of time using established fermentation techniques, they produce an abundant, regular supply of the desired product and they can be genetically manipulated easily than plants and animals (Dabananda and Kshetri, 2010; Tambekar et al., 2009). In addition, the protein products they produce are more stable than those from plants and animals.

Amylases are enzyme which hydrolyze starch molecule to give diverse products including dextrin and progressively smaller polymers composed of glucose units (Windish and Mhatre, 1965). Amylases can be derived from several sources including plants, animals and microorganisms. Microbial enzymes generally meet industrial demands. Today a large number of microbial amylases are available commercially and they have almost completely replaced chemical hydrolysis of starch in starch processing industry (Pandey et al., 2000).

This investigation attempts to isolate amylase and protease producing bacterial strain, Proteus sp. from sago effluent and optimization of culture conditions such as bacterial inoculum concentration, $\mathrm{pH}$ for the maximum production of amylase and protease using isolated Proteus sp.

\section{Materials and methods:-}

Optimization of enzymes production was carried out by using different bacterial inoculum concentration and pH.Amylase, protease and protein production was analyzed every 24 hours interval upto 72 hours.

\section{Sample collection:-}

Fresh sago effluent was collected from a sago effluent treatment plant in and around Salem District. The sample was collected in a 10 liter sterile plastic container. The container used for sample collection was pre-treated by washing with alcohol and later rinsed for three times with distilled water. It was dried for 1 hour at $30 \pm 5^{\circ} \mathrm{C}$ and allowed to cool at room temperature. At the collection point, container was rinsed with the sample thrice and then filled, corked tightly and taken to the laboratory for further analysis.

Isolation of amylase and protease producing microorganism:-

Sago effluent sample of $100 \mu \mathrm{l}$ was taken for serial dilution technique. The enrichment medium called nutrient agar of $60 \mathrm{ml}$ is prepared and spread plate method is performed for culture of microorganism. The nutrient agar plates were incubated at $37^{\circ} \mathrm{C}$. Isolated colonies were inoculated into the nutrient agar medium and are incubated for 24 hours.

\section{Identification of Bacteria:-}

The isolated pathogens were identified on the basis of Gram's reaction and biochemical characteristics (MacFaddin, 1980) and results were identified with the help of Bergey's Manual of systematic Bacteriology.

\section{Estimation of Amylase:-}

Total reducing sugar was estimated by dinitrosalicyclic (DNS) acid reagent method (Miller, 1959). DNSA reagent was prepared for $50 \mathrm{ml}$. Addition of DNSA reagent to the standard solution. The whole reaction mixture was incubated in boiling water bath for 15 minutes. Subsequently absorbance was measured at $540 \mathrm{~nm}$. Following the similar procedure, the filtrate obtained at different acid and alkali concentrations was estimated for reducing sugar by adding DNSA reagent.

\section{Estimation of Protease:-}

Tyrosine standard was prepared by taking $50 \mathrm{mg}$ of tyrosine in $100 \mathrm{ml}$ of distilled water and $500 \mu \mathrm{g} / \mathrm{ml}$ was taken. Then $1.0 \mathrm{ml}$ of sample was taken at different concentration and $5.0 \mathrm{ml}$ of sodium bicarbonate was added in each test 
tube and after 30 minutes incubation $1.0 \mathrm{ml}$ of folin reagent was added in each test tube and the optical density value was recorded at $660 \mathrm{~nm}$ in spectrophotometer (Singh et al., 1999).

\section{Estimation of Protein:-}

Bovine serum albumin standard was prepared and then $0.3 \mu \mathrm{l}$ of standard solution was taken and add $0.3 \mu \mathrm{l}$ of $\mathrm{NaOH}$ and kept for 10 minutes in boiling water. And then after few minutes add $3.0 \mathrm{ml}$ of complex reagent to each test tube and incubated for 10 minutes at room temperature. And then add $0.3 \mu 1$ of folin phenol reagent and kept for 30 minutes incubation at room temperature. Blue colour development was measured at $660 \mathrm{~nm}$ in spectrophotometer (Lowry et al., 1951).

\section{Results and discussion:-}

Various biochemical tests were done to identify the pathogen from sago effluent. The result obtained is given in the Table 1. The organism is identified as Proteus species. This Proteus species was used for production of amylase and protease.

Table 1:- Biochemical characterization of selected pathogen:-

\begin{tabular}{|c|c|c|}
\hline S.No. & Biochemical tests & Results \\
\hline 1 & Gram staining & Colorless \\
\hline 2 & EMB agar & Pale colonies \\
\hline 3 & Macconkey agar & Negative \\
\hline 4 & Mannitol agar & Positive \\
\hline 5 & Indole production test & Negative \\
\hline 6 & Voges-proskauer test & Negative \\
\hline 7 & Citrate utilization test & Positive \\
\hline 8 & Catalase test & Positive \\
\hline 9 & Oxidase test & Positive \\
\hline 9 & Nitrate reduction test & Acid butt/Alkaline slant \\
\hline 10 & Triple sugar iron agar test & Positive \\
\hline 11 & Methyl Red Test & \\
\hline
\end{tabular}

\section{Effect of various concentration of Bacterial Inoculum on amylase and protease production:-}

Optimization of various concentrations $(0.5 \%, 1.0 \%, 1.5 \%$ and $2.0 \%)$ of bacterial inoculum for amylase, protease and protein production was done (Table 2).

Bacterial inoculum concentration for maximum amylase production $(100 \mu \mathrm{g} / \mathrm{ml})$ was recorded at $1.0 \%$ and 2.0\%.Bacterial inoculum concentration for maximum protease production $(420 \mu \mathrm{g} / \mathrm{ml})$ was recorded at $0.5 \%, 1.0 \%$, $1.5 \%$. Bacterial inoculum concentration for maximum protein production $(8000 \mu \mathrm{g} / \mathrm{ml})$ was recorded at $0.5 \%, 1.0 \%$ respectively.

Table 2:- Effect of various concentration of Bacterial Inoculum on Amylase and protease production:-

\begin{tabular}{|c|c|c|c|c|c|c|c|c|c|c|}
\hline \multirow[t]{3}{*}{ S.No } & \multirow{3}{*}{$\begin{array}{c}\text { Bacterial } \\
\text { Inoculum }(\%)\end{array}$} & \multirow{2}{*}{\multicolumn{3}{|c|}{$\begin{array}{c}\text { Amylase }(\mu \mathrm{g} / \mathrm{ml}) \\
\text { Incubation period } \\
\text { in hours }\end{array}$}} & \multirow{2}{*}{\multicolumn{3}{|c|}{$\begin{array}{c}\text { Protease }(\mu \mathrm{g} / \mathrm{ml}) \\
\begin{array}{c}\text { Incubation period } \\
\text { in hours }\end{array} \\
\end{array}$}} & \multirow{2}{*}{\multicolumn{3}{|c|}{$\begin{array}{c}\text { Protein }(\mu \mathrm{g} / \mathrm{ml}) \\
\begin{array}{c}\text { Incubation period } \\
\text { in hours }\end{array} \\
\end{array}$}} \\
\hline & & & & & & & & & & \\
\hline & & 24 & 48 & 72 & 24 & 48 & 72 & 24 & 48 & 72 \\
\hline 1. & $0.5 \%$ & 80 & 80 & 92 & 260 & 310 & 420 & 3200 & 7500 & 8000 \\
\hline 2. & $1.0 \%$ & 92 & 92 & 100 & 290 & 310 & 420 & 2600 & 7500 & 8000 \\
\hline 3. & $1.5 \%$ & 80 & 86 & 92 & 280 & 310 & 420 & 2000 & 7500 & 7500 \\
\hline 4. & $2.0 \%$ & 72 & 86 & 100 & 280 & 290 & 360 & 1900 & 2600 & 4400 \\
\hline
\end{tabular}

Effect of various concentration of $\mathrm{pH}$ on amylase and protease production:

Optimization of various concentrations $(6,7,8,9)$ of $\mathrm{pH}$ was done. The results are shown in the Table 3 . The optimum $\mathrm{pH}$ for this study was found to be $\mathrm{pH}$ 9.Maximum production of amylase at $\mathrm{pH} 9$ was found to be 126 $\mu \mathrm{g} / \mathrm{ml}$. Maximum production of protease at $\mathrm{pH} 9$ was found to be $690 \mu \mathrm{g} / \mathrm{ml}$. Maximum production of $\mathrm{protein}$ at $\mathrm{pH}$ 9 was found to be $1200 \mu \mathrm{g} / \mathrm{ml}$. 
Table 3:- Effect of various concentration of $\mathrm{pH}$ on Amylase and protease production.

\begin{tabular}{|c|c|c|c|c|c|c|c|c|c|c|}
\hline \multirow[t]{3}{*}{ S.No. } & \multirow[t]{3}{*}{ pH } & \multirow{2}{*}{\multicolumn{3}{|c|}{$\begin{array}{c}\text { Amylase }(\mu \mathrm{g} / \mathrm{ml}) \\
\text { Incubation period } \\
\text { In hours }\end{array}$}} & \multirow{2}{*}{\multicolumn{3}{|c|}{$\begin{array}{c}\text { Protease }(\mu \mathrm{g} / \mathrm{ml}) \\
\text { Incubation period } \\
\text { In hours } \\
\end{array}$}} & \multirow{2}{*}{\multicolumn{3}{|c|}{$\begin{array}{c}\text { Protein }(\mu \mathrm{g} / \mathrm{ml}) \\
\text { Incubation period } \\
\text { In hours }\end{array}$}} \\
\hline & & & & & & & & & & \\
\hline & & 24 & 48 & 72 & 24 & 48 & 72 & 24 & 48 & 72 \\
\hline 1 & 6 & 28 & 40 & 86 & 160 & 240 & 440 & 200 & 800 & 1100 \\
\hline 2 & 7 & 22 & 34 & 86 & 130 & 210 & 490 & 200 & 800 & 1100 \\
\hline 3 & 8 & 20 & 40 & 86 & 120 & 220 & 480 & 900 & 1000 & 1000 \\
\hline 4 & 9 & 22 & 22 & 126 & 130 & 220 & 690 & 100 & 800 & 1200 \\
\hline
\end{tabular}

\section{Summary and Conclusion:-}

The isolated bacteria were identified as Proteus sp. based on the biochemical confirmation. The isolated bacteria were tested for suitability of different inoculums such as $0.5 \%, 1.0 \%, 1.5 \%$ and $2.0 \%$. It was found that $1.0 \%$ bacterial inoculum concentration shows maximum production of amylase ,protease and protein. The isolated bacteria were tested for maximum production of amylase,protease and protein at various $\mathrm{pH}$ ranges from 6-9. Optimum $\mathrm{pH}$ for amylase,protease and protein production was recorded at $\mathrm{pH}$ 9.The present study reports the production of Protease and Amylase by Sago effluent as a sole source of enzyme production using proteus sp. This proteolytic bacterium could be used effectively for industrial purpose.

\section{References:-}

1. Anbukumar,S., Narad Muni Prasad, Ashok Kumar,M.(2014).Effluent treatment for sago industry using Zeolie and activated carbon.Open Journal of Water pollution and Treatment.

2. Dabananda S.N and Kshetri P.(2010).A thermostable alkaline protease from a moderately haloalkalithermotolerant Bacillus subtilis strain SH1. Aust. J. Basic Appl. Sci.10: 5126-5134.

3. Lowry O.H, Rosebrough N.J, Farr A.L and Randall R.J.(1951) Protein measurement with the Folin phenol reagent. J. Biochem.,193: 265-275.

4. MacFaddin J.F. (1980) Biochemical tests for identification of medical Bacteria, $2^{\text {nd }}$ edition, Williams, Baltimore., 1-2.

5. Miller G.L.(1959).Use of dinitrosalicylic acid reagent for determination of reducing sugar. Anal Chem.,31: 426428.

6. Oyeleke,S.B., and Oduwole,A.A.(2009). Production of amylase by bacteria isolated from a cassava dumpsite in minna, Nigerstate, Nigeria. African Journal of Microbiology Research, 3(4): 143-146.

7. Pandey,A.,Nigam,P.,Soccol,C.R.,Socool,V.T.,Singh,D.\&Mohan,R.(2000).Advances in microbial amylases.Biotechnol.Appl.Biochem.,31:13-12.

8. Rai,S.K., Roy,J.K., and Mukherjee,A.K.(2010).Characterization of a detergent stable alkaline protease from a novel thermophilic strain Paenibacillus tezpurensis sp. Nov. AS-S24-II. Appl. Micribiol. Biotechnol. 85: 14371450 .

9. Singh J, Vohra R and Sahoo D.(1999).Alkaline protease from a new obligate alkalophilic isolate of Bacillus sphaericus. Biotech. Lett.,21: 921-924.

10. Synowiecki,J.,(2010).Some applications of thermophiles and their enzymes for protein processing. Afr. J. Biotechnology, 9: 7020-7025.

11. Tambekar D.H, Kalikar M.V, Shinde R.S, Vanjari L.B and Pawar R.G.(2009).Isolation and characterization of multiple enzyme producer Bacillus species from saline belt of purna river. J.Appl. Sci. Res.5: 1064-1066.

12. Windish W.W and Mhatre N.S. (1965).Microbial amylases. In: Wayne WU editor. Advances in applied microbiology. New York: Academic Press. 7: 273-304. 